\title{
Features of the organization of the educational process in the discipline "Civil Law" for students of the Military University of the Ministry of Defense of the Russian Federation
}

\author{
Alexey $V$. Barkov ${ }^{1,2 *}$, Yana $S$. Grishina ${ }^{3}$, Alexander $S$. Kiselev $^{2}$, and Alexeyh P. Sokolov ${ }^{2}$ \\ ${ }^{1}$ The Financial University under the Government of the Russian Federation (Financial University), \\ Moscow, Russia \\ ${ }^{2}$ Russian Defense Ministry Military University, Moscow, Russia \\ ${ }^{3}$ Russian State University of Justice, Moscow, Russia
}

\begin{abstract}
The article focuses on the high legal educational role of the "Civil Law" discipline in the development of the social activity of the cadet's personality. Difficulties in explaining the peculiarities of civil and legal relations to cadets with the participation of military organizations are determined. The current legislation does not take into account the special legal regime of the property of military organizations, due to the nature of the tasks being solved by the state. The thesis is developing that the graduate of the Military University should be ready to understand the current changes in the conditions of digitalization of the economy, constant improvement of skills, and sometimes retraining. The prospects of training practical skills through the participation of cadets in the legal clinic are noted. It is concluded that the digitalization of economics and law are the determining factors of influence on the educational process at the Military University.
\end{abstract}

\section{Introduction}

Civil law at all times has been a fundamental training course taught in all Russian and foreign legal universities, as the basis of the worldview, legal awareness, and professionalism of students. The problem of training cadets of military universities is the need to adapt the taught disciplines, both to the peculiarities of military-legal activity and modern trends, such as digitalization. The relevance of the study lies in the fact that at present, in the transition to a digital economy, the success of large-scale transformations taking place in the political, economic, social and other spheres depends on the quality of the obtained civilized knowledge of professional lawyers. The purpose of the work is to disclose the features of teaching the discipline "Civil Law" to cadets of the Military University, consisting of the need to form military-professional competencies. Objectives: to identify additional areas requiring study within the course of "civil law"; to determine the

*Corresponding author: barkov.a.v@bk.ru 
peculiarities of formation of military-professional competencies cadets; establish the impact of changes in civil law (emergence of the "digital rights" category) on the educational process.

\section{Methods}

The main methods used in the work were: methods of empirical cognition - comparativelegal, historical-legal, formal-logical methods, description, the system method, as well as analysis, synthesis, method of induction, and deduction.

\section{Results}

1) It was established that the peculiarities of the course "Civil Law" at the Military University are that as a result, the cadets have to acquire military-professional competencies that will allow them to apply the means of civil law regulation of public relations in the activities of military organizations: to know the operation of civil legislation during the period of a state of war or emergency; to determine the legal position of military property and its turnover capacity; to understand the peculiarities of tort responsibility of military organizations and civil and legal responsibility of military personnel.

2) The conclusion was made that in connection with the consolidation of digital rights in civil law, teachers of the civil law department should constantly work to improve pedagogical skills, scientific qualifications, regularly share experience at scientific and methodological events at all levels. It was supposed to make changes both in the lecture material and in the tasks for practice to bring cadets to relevant information with a bias in the military industry.

\section{Discussion}

The prosecutor's and investigative faculty of the Military University of the Ministry of Defense of the Russian Federation, as a law faculty aimed at training highly qualified specialists in the field of jurisprudence, cannot be an exception to this rule. Under these conditions, one of the main tasks of the educational process of cadets of the Military University is to master the specifics of the impact of civilized tools on market property relations, time-tested civil law categories, and designs, as well as current legislation and law enforcement practice [1].

The "Civil Law" discipline, in the fair opinion of E.A. Ryzhkovich, is the basis of the legal education of students studying in law schools, contributing to the development of the social activity of the individual [2]. The researcher notes that the attitude to the surrounding reality is determined by the knowledge of rights and obligations in various areas of social and economic life, their correlation with legal assessments of behavior available in the law. In her opinion, "Ambient reality is the relationship of people: property and personal nonproperty, which must be regulated both "from outside" (by law) and "from within" (legal consciousness of each individual)." The civil law branch is called upon to regulate these relations, in connection with this "it is this discipline that is the basis for the legal education of students who, wishing to become lawyers, will regulate public relations in real life both from the outside and from the inside" [2].

At the same time, given the importance of the legal educational function of civil law, it is impossible to recognize that the need to train qualified legal personnel for the needs of the Ministry of Defence of the Russian Federation gives rise to some peculiarities of teaching civil law to cadets of the Military University. In accordance with the main purpose 
of mastering the "Civil Law" discipline, which is to form a complex of competencies that ensure the readiness of a specialist effectively and professionally to function in accordance with the regular purpose related to the maintenance of state defense capability, the thematic study plan discipline "Civil law" in the specialty: 40.05.01 "Legal support of national security" is obliged to consider the peculiarities of participation of military organizations in data property relations determined by industry affiliation.

The specifics of mastering the "Civil Law" discipline by cadets of the Military University is that following the educational, practical and instructional objectives of the course, not only general professional and professional competencies should be formed, but also military professional competencies - the ability to qualify industry relations with the participation of military personnel, military administration bodies and military organizations arising in the field of defense and security.

In this regard, the teaching of civil law should focus on such features as the use of civil law regulation of public relations in the activities of military organizations; the effect of civil law during a period of martial law or a state of emergency; military organizations as legal entities; military property and its turnover ability; obligation relations with the participation of military organizations; tort liability of military organizations and their responsibility for non-fulfillment or improper fulfillment of civil obligations; civil liability of military personnel; protection of the rights of the Russian Federation of the rights to the results of intellectual activity of military and dual-purpose, etc.

At the same time, it should be clearly understood that civil-law relations with the participation of military organizations are limited, special in nature, due to the need for material and technical support for military organizations or arising in connection with causing harm, protecting the results of intellectual activity. Difficulties in explaining the peculiarities of these legal relations to cadets are that civil law often does not take into account the special legal status of military personnel, the regime of the property of military organizations and their responsibility, due to the nature of the tasks being solved. It seems that the lucky exception in this rule is only articles $1401-1405$ of the Civil Code of the Russian Federation, regulating the legal regime of secret inventions, to the most extent, taking into account military specificity [3].

In these circumstances, the teaching staff should undertake more in-depth research to find effective approaches to addressing the identified problems, not only to develop recommendations to improve legislation but also to train cadets in research skills. It is thought that one should not be afraid of putting these scientific problems in lectures, followed by collective discussion in seminars and practical sessions of possible options for correcting imperfect civil law rules. The main thing is to teach cadets how to think creatively. John McGinnis, Russell Mangas [4], Brindusa Kamelia Gorea [5], Henry Mann [6], V.I. Miller [7], J.W. Wegner [8], Shashikala Harpur, Rupay Rautdesay [9].

That is why it seems particularly important to develop the subject of reports, coursework, and diploma papers on the course "Civil Law", focused on real issues, taking into account the military component. Justifying the solution of the problem, the cadets will inevitably immerse themselves in the subject of research, gain scientific skills with legislation, law enforcement practice, doctrinal views of scientists, expanding your horizons.

Practical skills in working with real legal affairs can be obtained in legal clinics organizations where students, under the supervision of teachers and curators, can provide legal assistance to citizens free of charge. The benefits of these structures are indisputable: students acquire practical skills and citizens solve their legal problems. Legal clinics are dedicated to the work of Mohammad Meghdadi, Ahmad Nasab [10], Mahmoud Nora, Siti Hambali, Safinaz Hussain, Farid Jalil, Rohaid Nordin [11], Alper Uyumaz, Kemal Erdogan [12] and others authors. These structures are created on the basis of law universities in 
many countries. The legal clinic is a promising and significant tool in the educational process, including in military universities.

Along with the sectoral features of the mechanism of legal regulation of relations involving military organizations, organically combining private and public elements [3], cadets should assimilate the necessary amount of all civilized knowledge sufficient not only for the confident performance of duties following the regular purpose but also ensuring that full-fledged, high-quality legal education which meets the highest standards of advanced Russian universities. Quality legal education is necessary for a graduate of the Military University as a guarantee of their competitiveness as a professional lawyer. Not only the success of an officer's career but also their professional relevance at the end of military service depends on the knowledge and skills acquired at the university walls.

A graduate of the Military University should not get lost in the conditions of rapid digitalization of the economy and the free labor market but be prepared to understand the changes that are taking place, to constantly improve their qualifications, and sometimes even retrain. Teaching these skills is also the most important task of the faculty of the Department of Civil Law. To comply with the time, the teachers of the department themselves must constantly work on improving pedagogical skills, scientific qualifications, regularly share their experience at scientific and methodological events at all levels.

The coming digital age will inevitably affect all spheres of social life, transforming many established state and legal institutions under the influence of digital technologies [13], including military organization and administration. Even classical civilized institutions, in an attempt to find adequate answers to the challenges of digitalization, will be forced to renew. Since October 1, 2019, part one of the Civil Code of the Russian Federation includes article 141.1 "Digital Rights", and this is just the beginning, as the novella does not solve the problem of new object's civil rights, for example, cryptocurrency.

Researcher Catrina Denvir points out that "young people in England often resort to using online resources for solving various issues, including in the field of civil law. However, the usefulness of the Internet in this regard is still limited by the quality of the information provided and the ability to use and apply it in a meaningful way" [14]. That is why in the age of informatization it is necessary to pay increased attention to the development of learners' ability to search for legal information on the Internet and correctly apply digital rights.

Also, the inevitable convergence of real-life and virtual space will require adjustments to the theory of subjects of civil rights, recognition of the rights of a "digital personality" for "artificial intelligence" and put on the agenda the problem of its tort responsibility. "Smart contracts" concluded without the participation of a person on the Internet will adjust traditional civilized views on a deal, contract, obligation. Civil law aims to provide a solution to these complex problems. Today, as twenty years ago, the thesis of S.S. Alexeev about the fact that "the success of our reforms, the fate of our Fatherland, our future depends decisively on Civil Law" [15]. Accordingly, a systematic discussion of the novelties of civil legislation at the department is required.

\section{Conclusion}

The indicated questions cannot remain without the attention of the faculty of the Civil Law Department of the Military University and do not become the subject of study of cadets in the civil law classes. The driver determining the specifics and peculiarities of teaching civil law to cadets of the Military University of the Ministry of Defense of the Russian Federation will be - further digitalization of the economy 


\section{References}

1. A.P. Gorelik, Bulletin of the Moscow University of the Ministry of Internal Affairs of Russia 3, 115-117 (2013)

2. E.A. Ryzhkovich, "The discipline "Civil Law" as an effective factor in the legal education of students of law schools": author. diss. ... cand. ped sciences (Moscow, 2005)

3. V.N. Startsun, ENI "Military Law" 1 (2014) Available at: www.voennoepravo.ru

4. J. O. McGinnis, R. D. Mangas, International Review of Law and Economics 38, 117 131 (2014)

5. B. C. Gorea, Procedia - Social and Behavioral Sciences 46, 3124-3128 (2012)

6. H. G. Manne, International Review of Law and Economics 38, 107-116 (2014)

7. V. I. Miller, Procedia - Social and Behavioral Sciences 1667, 427-433 (2015)

8. J. W. Wegner, Education for the Legal Profession, International Encyclopedia of Education (Third Edition) (Elsevier Ltd., 2010)

9. Sh. Gurpur, R. Rautdesai, Procedia - Social and Behavioral Sciences 157, 254-265 (2014)

10. M. M. Meghdadi, A. E. Nasab, Procedia - Social and Behavioral Sciences 15, 30143017 (2011)

11. M. Z. Mohd Nor, S. N. Hambali, S. M. Hussein, F. Jalil, R. Nordin, Procedia - Social and Behavioral Sciences 18, 527-533 (2011)

12. A. Uyumaz, K. Erdoğan, Procedia - Social and Behavioral Sciences 174, 2116-2122 (2015)

13. E.V. Talapina, Journal of Russian Law 2, 5-17 (2018)

14. C. Denvir, Computers \& Education 92-93, 204-220 (2016)

15. S.S. Alekseev, Private law: a journalistic essay (Statute, Moscow, 1999) 